\title{
QUALITATIVE ANALYSIS OF ORAL LACTOBACILLI PARAMETERS AT DIFFERENT STAGES OF HUMAN LIFE CYCLE AND DIFFERENT CARIES INDICES
}

DOI: $10.36740 /$ WLek202006124

\author{
Andrii V. Zaytsev, Olha N. Boychenko, Yuliia V. Sidash, Natalya V. Kotelevska, Anatolii K. Nikolyshyn \\ UKRAINIAN MEDICAL STOMATOLOGICAL ACADEMY, POLTAVA, UKRAINE
}

\begin{abstract}
The aim of this article is to provide the detailed study of the changes in the lactobacilli indices of the oral biotope in health and in caries progression in individuals. Materials and methods: Materials included on reports and data of research projects conducted at the Department of Therapeutic Dentistry and Department of Microbiology, Virology and Immunology, Ukrainian Medical Stomatological Academy (Poltava), at the Department of Microbiology of Danylo Halytsky National Medical University (Lviv), completed in 2013;research data documented by the Department of Microbiology, Medical Stomatological Institute (now Ukrainian Medical Stomatological Academy, Poltava) in 1978; literature related to the subject matter. Methodology: the standard methods of dental examination recommended by WHO; methods of system analysis and system approach, bibliosemantic analysis .

Results: The presented results indicate that the number of representatives of different types of oral microflora in the oral microbiocenosis is different at different stages of human life. The content of Lactobacilli in children decreases following the rise even under increased dmft indices.

Conclusions: The data observed are of great clinical interest when considering the role of Lactobacilli in the protection of the host organism and the initiation of the carious process.
\end{abstract}

KEY WORDS: oral cavity, dental caries, Lactobacilli, microbiocenosis.

Wiad Lek. 2020;73(6):1207-1210

\section{INTRODUCTION}

The oral microflora plays an important role in maintaining the integrity of the oral cavity and contributing to overall health. Microbiota is known to perform the following key functions as to maintain metabolism, provide the protection and trophic support. Under certain conditions, associate members of oral microbiocenosis trigger pathological processes, the intensity and prevalence of which can reach critical values. First and foremost, this is a carious disease and inflammatory periodontal diseases $[1,2]$. Cariology research papers allege that the most aggressive representatives of oral microbiocenosis are Str. mutans and Lactobacillus.

The ability of these bacteria to produce inorganic acids followed by enamel demineralization has been well described in laboratory, experimental, and clinical studies by O. Fejerskov, E.A.M. Kidd (2004); J.J. Soet et al. (2000). Loesche et al. in their reports (1984) have proven that Str. Mutans are agents initiating aggression on the dental enamel leading to demineralization. The clinical studies on the caries development in humans under constant monitoring of the changes in microbiological composition in the dental fissures lasting over 18 months have demonstrated Str. mutans is the causative agent of the enamel demineralization onset. It should be stresses that 12 months earlier before the detection of initial caries in the fissures, the number of Lactobacilli increased [3]. At the same time, lactobacilli and streptococci permanently residing in the oral cavity are antagonistic to numerous representatives of transient microflora (Sarcinae, Escherichia coli, Proteus, etc.) and contribute to their expelling from the oral cavity [4].

An analysis of the isolation rate of bacteria from the biotopes studied indicates that there is no necessity to detect the entire spectrum of the microbial composition of the biocenosis. The most exponential (indicative) microorganisms, and in the oral cavity as well, are all the same lactic acid bacteria, streptococci, staphylococci, and Candida fungi. Some researchers consider that a decrease in their culturing rate indicates a microflora imbalance [5]. All this suggests that the thorough study of representatives of the human microbiocenoses, especially their exponential forms, is of great clinical relevance.

\section{THE AIM}

The aim of this article is to provide the detailed study of the changes in the lactobacilli indices of the oral biotope in health and in caries progression in individuals.

\section{MATERIALS AND METHODS}

Materials included on reports and data of research projects conducted at the Department of Therapeutic Dentistry and Department of Microbiology, Virology and Immunology, 


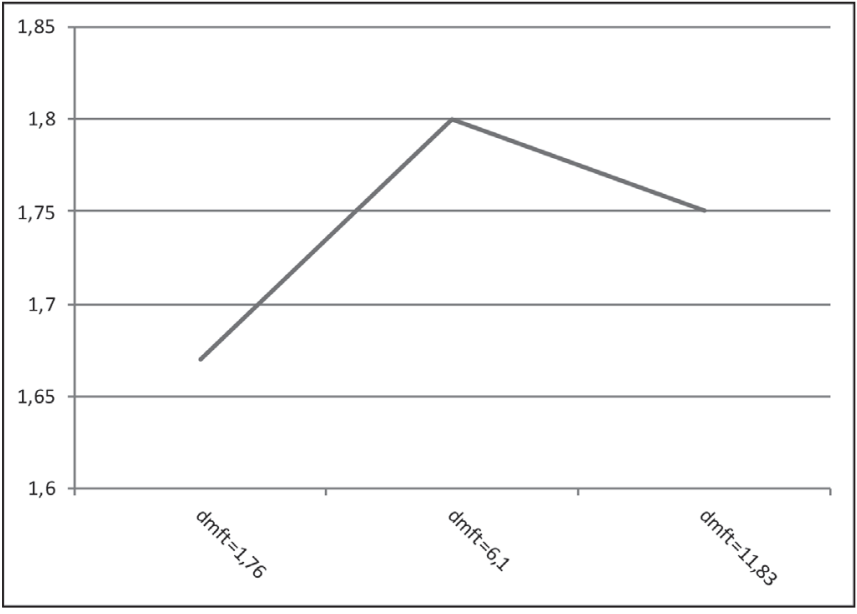

Fig. 1. The number of Lactobacilli in the oral cavity $\left(x 10^{2} \mathrm{U} / \mathrm{ml}\right)$ in 12 year old children depending on the dmft index.

Table I. The number of Lactobacilli in the oral cavity $\left(\times 10^{2} \mathrm{U} / \mathrm{ml}\right)$ in 12 year old children depending on the $\mathrm{dmft}$ index

\begin{tabular}{cccc}
\hline $\begin{array}{c}\text { Microbial } \\
\text { flora }\end{array}$ & $\mathbf{d m f t}=\mathbf{1 , 7 6}$ & $\mathrm{dmft}=\mathbf{6 , 1}$ & $\mathbf{d m f t}=\mathbf{1 1 , 8 3}$ \\
\hline $\begin{array}{c}\text { Lactobacillus } \\
\left(\times 10^{2} \mathrm{U} / \mathrm{ml}\right)\end{array}$ & $1,67 \pm 0,2 \times 10^{2}$ & $1,8 \pm 0,19 \times 10^{2}$ & $1,75 \pm 0,2 \times 10^{2}$ \\
\hline
\end{tabular}

Ukrainian Medical Stomatological Academy (Poltava), as well as at the Department of Microbiology of Danylo Halytsky National Medical University (Lviv), completed in 2013. We also employed research data documented by the Department of Microbiology, Medical Stomatological Institute (now Ukrainian Medical Stomatological Academy, Poltava) in 1978, as well as an available literature related to the subject matter. Methodology included the standard methods of dental examination recommended by WHO, analysis of the above mentioned research reports as well as bibliosemantic analysis of available relevant literature.

\section{RESULTS}

Lactobacillus group is known as a widespread species of gram-positive anaerobic or microaerophilic non-sporeforming lactic acid bacteria. They grow at a temperature of $+15-+45^{\circ} \mathrm{C}$, the optimum temperature for their growth is $+30^{\circ} \mathrm{C}$. The most favourable conditions for Lactobacilli are at low $\mathrm{pH}$ values, typically $3.2-3.5$, and at low oxygen content. In the process of normal metabolism, they are able to produce lactic acid, hydrogen peroxide; they can also produce lysozyme and substances with antibiotic properties as reuterin, plantaricin, lactocidin, lactoline. Moreover, hetero-fermenting species of Lactobacilli as end products can produce acetic acid and carbon dioxide. They are found in the intestines, on the skin and on the mucous membranes of humans and animals. Milk for Lactobacillus is the most optimal medium [6].

Lactobacilli colonize the human body from the moment of its birth and are identified on the 5th day following this event $[7,8,9]$. There are data reporting that by the age of
4 months exclusively milk-fed infants and bottle-fed ones demonstrate marked differences in the oral microbiota. The milk-fed infants were found to have an increased level of probiotic microorganisms as Lactobacillus johnsonii / L. gasseri, L. paracasei / L. casei $[8,9]$. This is probably due to the fact that the main regulatory factor in the microbiocenosis is nutrients that provide the proper ecological niche for microorganisms colonizing. During the colonization of the niche with symbionts, such a separation of metabolic functions between microorganisms gets settled down, and the mutual exchange between their metabolites becomes inevitable and mandatory [10].

Thereupon, it is appropriate to refer to the study conducted in the last quarter of the twentieth century at the Department of Microbiology at former Poltava Medical Dental Institute (now Ukrainian Medical Stomatological Academy). The conclusion was drawn that the frequency rate of isolation of Lactobacilli bacteriocinogenic strains from saliva of individuals with dental caries was 1.75 times higher than from saliva of healthy people $(\mathrm{p}<0.05)$, and in 1.9 times higher than from saliva of individuals with periodontal disease $(\mathrm{p}<0.05)$ (note: bacteriocins are substances with narrow spectrum antibiotic properties aimed at homologous or related bacterial species; parodontosis was called as parodontitis) [11]. Due to the ability to secrete bacteriocins and other active substances, Lactobacilli inhibit the growth of putrefactive and opportunistic pathogens, and thus, manifest their protective function relative to the tissues of the host organism [12].

A part of the research project performed at the Department of Microbiology, Danylo Halytsky Lviv National Medical University in 2013 relates to a comprehensive dental examination of children aged 12 years. And one of the tasks of this research was to determine and assess the quantitative indicators of Lactobacilli in the oral cavity of children with different dmft indices (Fig. 1, Table 1).

The authors explain the decrease in the number of Lactobacilli following the their rise under an increase in the $\mathrm{dmft}$ indies by the development of conditions, which promote the growth of opportunistic and pathogenic microflora, such as Proteus, a gram-negative bacillus of the non-fermenting group that leads to the formation of alkaline $\mathrm{pH}$ in the oral cavity [13].

Some results obtained by the Department of Therapeutic Dentistry and the Department of Microbiology, Virology and Immunology, Ukrainian Medical Stomatological Academy (Poltava) in 2013 on studying the quantitative indicator of Lactobacilli index in young people aged 19-25 years with different DMF indices and an intact periodontium are presented in Fig. 2 and in Table II.

The researchers suggest that reducing competition for adhesion receptors and nutrients from the stabilizing microflora as well as its lowering production of inhibitors contribute to excessive colonization with cariogenic and opportunistic microflora, including Lactobacilli, which are able to metabolize carbohydrates to lactic acid, and tolerant to low $\mathrm{pH}$ values of the medium [14].

When summing up the results on indicators of Lactobacilli, their changes can be presented as seen in the Figure 3 . 
Table II. The number of Lactobacilli in oral cavity $\left(\times 10^{2} \mathrm{U} / \mathrm{ml}\right)$ in $19-25$ year old individuals depending on DMF indices

\begin{tabular}{cccc}
\hline Microbial flora & DNF $=\mathbf{0}$ & DMF=3,4 & DMF $=\mathbf{7 , 2}$ \\
\hline Lactobacillus $\left(\times 10^{2} \mathrm{U} / \mathrm{ml}\right)$ & $125,89 \pm 0,05 \times 10^{2}$ & $251,19 \pm 0,13 \times 10^{2}$ & $794,33 \pm 0,18 \times 10^{2}$ \\
\hline
\end{tabular}

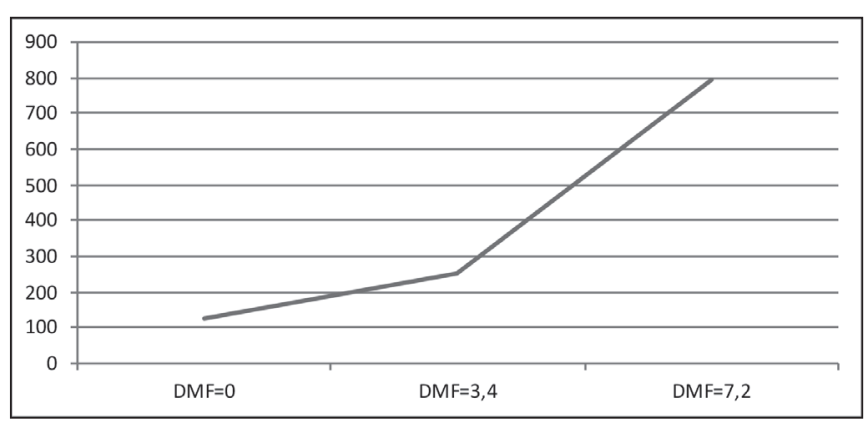

Fig. 2. The number of Lactobacilli in oral cavity $\left(x 10^{2} \mathrm{U} / \mathrm{ml}\right)$ in $19-25$ year old individuals depending on DMF indices.

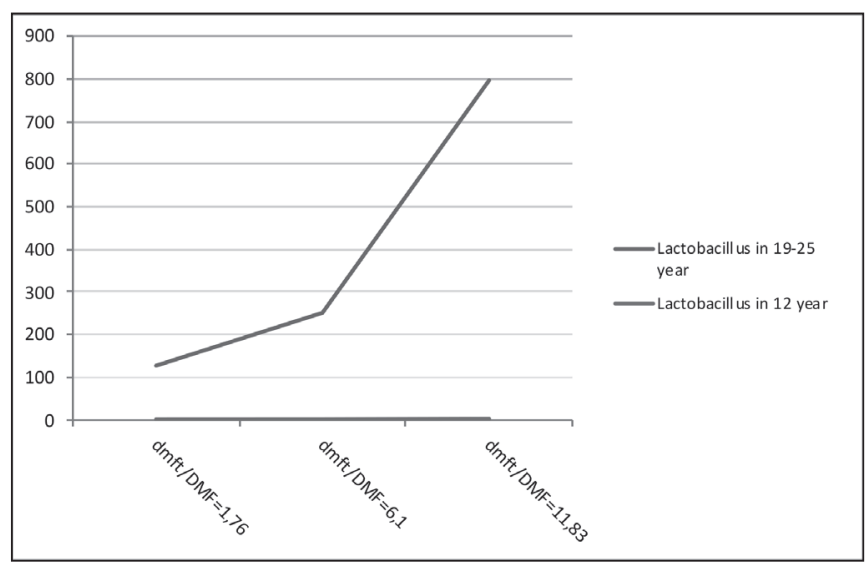

Fig. 3. The number of Lactobacilli in the oral cavity $\left(x 10^{2} \mathrm{U} / \mathrm{ml}\right)$ in 12 year old children and $19-25$ young adults depending on dmft / DMF indices.

The graph in Fig. 3 shows that the variability in the number of oral Lactobacilli is the most noticeable depending on DMF indices in 19-25-year-old youth, while in 12-year-old children the above changes with this scaling are insignificant. This might be very interesting by its consequences.

\section{DISCUSSION}

The presented results indicate that the number of representatives of different types of oral microflora in the oral microbiocenosis is different at different stages of human life. The content of Lactobacilli in children decreases following the rise even under increased $\mathrm{dmft}$ indices.

We can suggest some explanation for this phenomenon. One of them is associated with a change in the quantitative and qualitative microbial composition, and namely, an increase in opportunistic microbes and appearance of pathogenic microbes that can result in the shift in the indicators of the oral biotope, including its $\mathrm{pH}$.

Another explanation is based on the assumption that representatives of related species can produce substances affecting other species and thus leading to the dominance of one species, possibly the most pathogenic: as a consequence, its closely related representatives vanish. However, under the changes in the number of oral Lactobacilli depending on the DMF indices in $19-25$ year old individuals, this variability is insignificant.

The data observed are of great clinical interest when considering the role of Lactobacilli in the protection of the host organism and the initiation of the carious process.

\section{CONCLUSIONS}

The investigation of the representatives of human oral microbiocenosis should be continued not only in a quantitative but in qualitative dimension, which is strongly related to the functioning of microorganisms and outcomes of their functioning. This requires searching for new sophisticated methodology and the updating the existing techniques aimed at identifying and in-depth studying the functional parameters of the oral microbiota.

\section{REFERENCES}

1. Boychenko 0.N., Kotelevskaya N.V., Nikolishin A.K., i dr. Morfofunktsionalnaya harakteristika nazubnogo naleta. Visnyk problem biolohii i medytsyny [Morphological and functional characteristics of plaque]. 2016; 4(134): 9-15.

2. Bublii T.D. Monitorynh stomatolohichnoi zakhvoriuvanosti studentivmedykiv [Monitoring of dental morbidity of medical students]. Pivdennoukrainskyi medychnyi naukovyi zhurnal. 2014; 7 (07): 17-9.

3. Leus P.A. Otlozheniya na zubah. Rol zubnogo naleta v fiziologii i patologii polosti rta [Deposits on the teeth. The role of plaque in the physiology and pathology of the oral cavity] [ucheb.-metod. posobie]. Minsk: BGU; $2007,32 \mathrm{p}$.

4. Ohta H., Kato K., Fukui K. et al. Microbial interactions and the development of periodontal disease. J. Periodontal Res. 1991; 26(3): 255-7.

5. Penders J., Vink C., Driessen C., et al. Quantification of Bifido-bacterium spp., Escherichia coli and Clostridium difficile in faecal samples of breast-fed and formula-fed infants by real-time PCR. FEMS Microbiol Lett. 2005; 243(1): 141-7.

6. Bochkareva 0.P., Krasnozhenov E.P., Goldberg V.E., idr. Mikroflora polosti rta kak indikator disbioticheskih rasstroystv u bolnyih rakom molochnoy zhelezyi [Microflora of the oral cavity as an indicator of dysbiotic disorders in patients with breast cancer]. Sibirskiy onkologicheskiy zhurnal. 2013; 5 (59): 24-6.

7. Lactobacillus (laktobakterii il laktobatsillyi, rod bakteriy) [Lactobacillus (lactobacilli or lactobacilli, a genus of bacteria)]. URL: https://www. gastroscan.ru/handbook/118/1906.

8. Ryimashevskiy A.N., Naboka Yu.L.,Svirava E.G., i dr. Vliyanie mikrofloryi materi na stanovlenie mikrotsenoza kishechnika rebenka v period grudnogo vskarmlivaniya [The influence of the microflora of the mother on the formation of the microcenosis of the intestines of the baby during breastfeeding]. Vestnik Natsionalnogo mediko-hirurgicheskogo Tsentra im. N.I. Pirogova. 2012; 7, 1: 84-2.

9. Bezirtzoglou E., Tsiotsias A., Welling G.W. Microbiota profile in feces of breast- and formula-fed newborns by using fluorescence in situ hybridization (FISH). Anaerobe. 2011; 17 (6): 478-482. 
10. Simonova E.V., Ponomareva 0.A. Rol normalnoy mikrofloryiv podderzhanii zdorovya cheloveka [The role of normal microflora in maintaining human health]. Sibirskiy meditsinskiy zhurnal. 2008; 8: 20-5.

11. Fillipov V.A. Harakteristika bakteriotsinogennosti laktobatsill polosti rta. Stomatologiya [Characterization of the bacteriocinogenicity of oral lactobacilli]. 1978; 6: 19-21.

12. Novokshonov A.A., Sokolova N.V. Fiziologicheskie funktsii laktobakteriy $v$ organizme i effektivnost ih primeneniya $v$ sostave probiotikov $v$ pediatricheskoy praktike [Physiological functions of lactobacilli in the body and the effectiveness of their use as part of probiotics in pediatric practice]. URL: https://umedp.ru/articles/fiziologicheskie_funktsii_ laktobakteriy_v_organizme_i_effektivnost_ikh_primeneniya_v_ sostave_probiot.html.

13. Smoliar N.I., Baryliak D.lu. Mikroflora zubnoho nalotu u ditei zalezhno vid intensyvnosti kariiesu zubiv [Plaque microflora in children depending on the intensity of dental caries]. Profilaktychna ta dytiacha stomatolohiia. 2013. 2 (9); 26-9.

14. PetrushankoT.O., CheredaV.V., Loban H.A. Yakisnyisklad mikrobiotsenozu porozhnyny rota osib molodoho viku z riznoiu intensyvnistiu kariiesu. Svit medytsyny ta biolohii [Qualitative composition of the oral microbiocenosis of young people with different intensity of caries]. 2013; 1: 57-9.

This research is a part of the research project "Mechanisms of impact produced by nosogenic factors on the oral status of individuals with somatic pathologies: the approaches in their correction and prevention" conducted at the Department of Therapeutic Dentistry, Ukrainian Medical Stomatological Academy (State Registration 0115 U001138)
ORCID and contributorship:

Andrii V. Zaytsev, - $0000000331235681^{A, F}$

Olha N. Boychenko, - $0000000310795719^{B, D}$

Yuliia V. Sidash, - $000000018955754 X^{B, C, D}$

Natalya V. Kotelevska, - $000000027095653 X^{B, C}$

Anatolii K. Nikolyshyn - $0000000243957828^{E}$

\section{Conflict of interest:}

The Authors declare no conflict of interest.

\section{CORRESPONDING AUTHOR Yuliia V. Sidash}

Ukrainian Medical Stomatological Academy

Shevchenka st, 23, 36011, Poltava, Ukraine

tel: +380509809865

e-mail: u.v.sidash@ukr.net

Received: 21.02 .2020

Accepted: 30.04 .2020 